\title{
Pengaruh Model Pembelajaran Discovery Learning Menggunakan Alat Peraga Jam Baretika terhadap Pemahaman Konsep Siswa pada Materi Barisan dan Deret Aritmetika
}

Anggun Purnamasari ${ }^{1}$, Widiawati, Indah Widyaningrum

${ }^{1}$ Sekolah Tinggi Keguruan dan Ilmu Pendidikan (STKIP)

Muhammadiyah Pagar Alam

'anggunpsari88@gmail.com

\begin{tabular}{l}
\hline \hline Article Info \\
\hline Article history: \\
Received Sep $3^{\text {rd }}, 2020$ \\
Revised Dec $31^{\text {th }}, 2020$ \\
Accepted Dec $31^{\text {th }}, 2020$ \\
\hline
\end{tabular}

Keywords:

Discovery Learning;

Baretic clock;

Concept Understanding

The purpose of this study was to determine the effects of the discovery learning model using Baretic Clock teaching aids on students' understanding of the concept of arithmetic sequences and arithmetic series in class XI SMA Negeri 4 Kota Pagar Alam for the 2019/2020 academic year. The research method used in this research is the experimental method in the category of Pre-Test Post-Test Only Control Design. The population in this study were students of class XI MIPA at SMA Negeri 4 Kota Pagar Alam. Meanwhile, the samples in this study were students of class XI MIPA 4 and XI MIPA 6, respectively 34 and 33 students. Data collection using documentation and test methods. After the data is collected, the normality and homogeneity test is carried out to find out the data to be analyzed comes from data that is normally distributed and homogeneous. From the results of this analysis, the data were processed based on the conceptual understanding indicator to determine the effect of the Discovery Learning model using baretic clock teaching aids on students' conceptual understanding. So the results of the study show that there is an effect of the Discovery Learning model using baretic clock teaching aids on students' conceptual understanding of the arithmetic sequence and series material for class XI SMA Negeri 4 Kota Pagar Alam for the 2019/2020 academic year.

Kata Kunci:

Discovery Learning; Jam baretika; Pemahaman Konsep

\section{Abstrak}

Tujuan penelitian ini untuk mengetahui pengaruh model pembelajaran discovery learning menggunakan alat peraga jam baretika terhadap pemahaman konsep siswa pada materi barisan dan deret aritmetika kelas XI SMA 
Negeri 4 Kota Pagar Alam Tahun Pelajaran 2019/2020. Metode penelitian yang digunakan dalam penelitian ini adalah metode eksperimen kategori Pre-Test Post-Test Only Control Design. Populasi dalam penelitian ini adalah siswa kelas XI MIPA SMA Negeri 4 Kota Pagar Alam. Sedangkan yang menjadi sampel dalam penelitian ini adalah siswa kelas XI MIPA 4 dan XI MIPA 6 yang masing-masing berjumlah 34 dan 33 siswa. Pengumpulan data menggunakan metode dokumentasi dan tes. Setelah data terkumpul, uji normalitas dan homogenitas dilakukan untuk mengetahui data yang akan dianalisis berasal dari data yang berdistribusi normal dan homogen. Dari hasil analisis tersebut, data diolah berdasarkan indikator pemahaman konsep untuk mengetahui pengaruh model pembelajaran Discovery Learning menggunakan alat peraga jam baretika terhadap pemahaman konsep siswa. Sehingga hasil penelitian menunjukkan bahwa ada pengaruh model pembelajaran Discovery Learning menggunakan alat peraga jam baretika terhadap pemahaman konsep siswa pada materi barisan dan deret aritmetika kelas XI SMA Negeri 4 Kota Pagar Alam Tahun Pelajaran 2019/2020.

\section{PENDAHULUAN}

Konsep barisan dan deret sangat penting peranannya dalam kehidupan sehari-hari maupun dalam ilmu pengetahuan dan teknologi. Pemahaman dalam materi ini akan membantu siswa dalam menyelesaikan masalah matematika yang ada pada kehidupan nyata. Misalnya dalam mengukur kecepatan kendaraan pada speedometer yang mana pada speedometer akan memuat beberapa barisan angka yang memiliki pola tertentu membentuk sebuah barisan aritmatika (Kharisma, 2018). Menurut Fauziah, Juandi \& Purniati (2017), pokok bahasan barisan dan deret adalah salah satu konsep yang banyak menggunakan rumus atau prosedur. Siswa akan mengalami kesulitan untuk menggunakan konsep yang ada pada barisan dan deret ketika siswa hanya menghapal rumus atau aturan tanpa memahaminya.

Menurut Fauziah, Juandi \& Purniati (2017), kebanyakan siswa hanya menghapalkan prosedur dan rumus pada pembelajaran konsep barisan. Hal ini menyebabkan banyak siswa yang tidak dapat menjawab 
soal-soal berbentuk aplikasi dan membutuhkan pemahaman konsep yang lebih mendalam. Sedangkan menurut Saifuddin, dkk. (2018), siswa tidak mengerti prinsip atau petunjuk yang dibutuhkan untuk mengerjakan soal. Siswa tidak memahami dan tidak mengerti bagaimana mengerjakan soal tersebut. Sehingga mereka mengerjakan soal dengan asal-asalan tanpa tahu model matematika yang harus dibuat. Menurut A'raf, Tahmir \& Rohman (2015), matematika dianggap perlu diberikan kepada peserta didik dari jenjang pendidikan dasar hingga perguruan tinggi. Tujuannya adalah untuk membekali peserta didik dengan kemampuan berpikir logis, analisis, sistematis, kritis, kreatif, serta kemampuan bekerja sama. Salah satu cara atau alternatif lain untuk memperbaiki kualitas proses pembelajaran di sekolah adalah diperlukan sebuah kurikulum. Menurut Kemdikbud (2014), dalam kurikulum 2013 pembelajaran matematika hendaknya dimulai dari suatu pengamatan permasalahan yang konkret, rumus-rumus diturunkan oleh siswa dan permasalahan yang diajukan harus dapat dikerjakan siswa hanya dengan rumus-rumus dan pengertian dasar (tidak hanya menggunakan tetapi juga memahami asal-usulnya), serta pembelajaran dirancang supaya siswa harus berfikir kritis untuk menyelesaikan permasalahan yang diajukan.

Model pembelajaran penemuan (discovery learning) merupakan salah satu model pembelajaran yang diutamakan dalam implementasi kurikulum 2013 yang mengacu pada keingintahuan siswa dan memotivasi siswa untuk melanjutkan pekerjaannya hingga mereka menemukan jawabannya. Model ini menempatkan guru sebagai fasilitator dan membimbing siswa hanya saat ia perlukan. Siswa didorong untuk berfikir dan menganalisis sendiri hingga "menemukan" prinsip umum berdasarkan bahan atau data yang telah disediakan guru (Kodir. 2018:229). Salmi (2014), mengemukakan kelebihan dari model pembelajaran discovery learning diantaranya dapat menimbulkan rasa senang pada peserta didik karena menumbuhkan rasa menyelidiki dan berhasil, peserta didik akan mengerti konsep dasar dan ide-ide lebih baik, Mendorong peserta didik berpikir dan bekerja atas inisiatif sendiri, serta peserta didik belajar dengan memanfaatkan berbagai jenis sumber belajar. Selain kelebihan, model pembelajaran discovery learning juga 
mempunyai kekurangan. Hosnan (Salmi, 2014) mengemukakan kekurangan dari model pembelajaran discovery learning dapat menyita banyak waktu karena guru dituntut mengubah kebiasaan mengajar pada umumnya sebagai pemberi informasi menjadi fasilitator, motivator, dan pembimbing, dan kemampuan berpikir rasional peserta didik ada yang masih terbatas, serta tidak semua peserta didik dapat mengikuti pelajaran dengan cara ini.

Melalui pembelajaran penemuan (discovery learning) siswa diharapkan terlibat dalam penyelidikan suatu hubungan, mengumpulkan data, dan menggunakannya untuk menemukan hukum atau prinsip yang berlaku pada kejadian tersebut. Oleh karena itu, seorang guru harus mempunyai kemampuan dalam mengembangkan dan mendesain materi pembelajaran sehingga tidak tergantung pada buku teks yang sudah ada. Membuat alat peraga menjadi salah satu penunjang pembelajaran penemuan.

Jam Baretika adalah alat peraga yang dibuat berbentuk jam yang mempunyai dua buah jam dengan fungsi berbeda serta mempunyai komponen-kompenen pendukung lainnya. Jam baretika digunakan pada materi barisan dan deret aritmatika yang berfungsi sebagai alat untuk menemukan bilangan-bilangan aritmatika. Jam baretika bertujuan untuk membuat siswa terlibat aktif di dalam menemukan sendiri bilanganbilangan serta konsep barisan dan deret aritmatika.

Beberapa penelitian sebelumnya tentang model pembelajaran discovery learning diantaranya Riyanti (2017), bahwa pembelajaran dengan menggunakan model discovery learning berbantuan alat peraga Pancabana memiliki dampak positif dalam meningkatkan prestasi belajar peserta didik yang ditandai dengan peningkatan ketuntasan belajar, keaktifan belajar.

\section{METODE PENELITIAN}

Metode penelitian adalah cara yang akan digunakan oleh peneliti dalam mengumpulkan data penelitian (Arikunto, 2010:203) dan penelitiannya. Metode yang digunakan dalam penelitian ini adalah metode eksperimen. Menurut Arikunto (2010:203), eksperimen adalah 
suatu cara untuk mencari hubungan sebab akibat (hubungan kausal) antara dua faktor yang sengaja ditimbulkan oleh peneliti dengan mengeliminasi atau mengurangi atau menyisihkan faktor-faktor lain yang menganggu, eksperimen selalu dilakukan dengan maksud untuk melihat hasil perlakuan.

Penelitian ini menggunakan desain Pretest Posttest Control Design, Desain penelitian ini digunakan karena penelitian ini menggunakan kelompok kontrol, adanya dua perlakuan yang berbeda, dan pengambilan sampel secara acak kelas. Tes matematika dilakukan satu kali yaitu sesudah proses pembelajaran, yang disebut post-test. Secara singkat desain penelitian tersebut adalah sebagai berikut:

\section{(Arikunto, 2010:125)}

\begin{tabular}{llll}
\hline $\mathrm{E}_{1}$ & $\mathrm{X}$ & $\mathrm{O}_{2}$ \\
\hline $\mathrm{K}_{3}$ & $\mathrm{X}$ & $\mathrm{O}_{4}$ \\
\hline
\end{tabular}

Dengan desain tersebut dalam penelitian ini terdapat dua kelompok yang dipilih secara acak (random), kelompok pertama adalah kelas eksperimen (E) adalah kelompok yang diberikan perlakuan dengan menggunakan model pembelajaran discovery learning dan kelompok kedua adalah kelas kontrol $(\mathrm{K})$ yang tidak diberikan perlakuan dengan menggunakan model pembelajaran discovery learning. Post-test (tes akhir) dilakukan pada akhir pertemuan untuk mengetahui pemahaman konsep siswa kelas eksperimen dan kelas kontrol. Pemahaman konsep yang dimaksud pada kelas eksperimen yaitu, setelah diterapkannya model pembelajaran Discovery Learning menggunakan alat peraga jam baretika. Sedangkan, pada kelas kontrol setelah diterapkannya pembelajaran konvensional.

\section{HASIL PENELITIAN DAN PEMBAHASAN}

Berdasarkan hasil analisis data penelitian yang telah dilakukan melalui uji-t pada taraf nyata 5\%, hasil uji hipotesis menunjukkan bahwa $t_{\text {hitung }}>t_{\text {tabel }}$ yaitu 3,82 $>1,99$ yang menyatakan $t_{\text {hitung }}$ tidak terletak pada daerah terima $\mathrm{H}_{\mathrm{o}}$. Dengan demikian dapat disimpulkan bahwa ada 
pengaruh model pembelajaran Discovery Learning menggunakan alat peraga jam baretika terhadap pemahaman konsep siswa pada materi barisan dan deret artimetika kelas XI SMA Negeri 4 kota Pagar Alam tahun pelajaran 2019/2020.

Berdasarkan penjelasan, terlihat bahwa dengan menggunakan model pembelajaran Discovery Learning menggunakan alat peraga jam baretika terhadap pemahaman konsep siswa dapat membantu peserta didik memahami konsep lebih baik jika dibandingkan dengan penggunaan metode pembelajaran biasa (konvensional) karena dalam proses pembelajarannya peserta didik dituntut untuk berpikir dan bekerja sama dengan pasangannya masing-masing dalam mengerjakan soal, sehingga dapat membuat mereka tidak segan untuk bertanya kepada temantemannya yang lain atau kepada pendidik tentang masalah yang belum bisa mereka selesaikan, hal tersebut yang selalu menuntut peserta didik aktif dan mengungkapkan pendapat atas inisiatifnya sendiri, sehingga model pembelajaran Discovery Learning menggunakan alat peraga jam baretika memberikan pengaruh positif karena peserta didik dapat membangun konsepnya secara individu.

Pada awal penggunaan model pembelajaran Discovery Learning menggunakan alat peraga jam baretika di kelas eksperimen, peserta didik terlihat bingung dan sulit beradaptasi dengan proses dalam pembelajaran Discovery Learning menggunakan alat peraga jam baretika. Hal ini karena peserta didik telah terbiasa menggunakan metode pembelajaran biasa (konvensional), sehingga ketika peserta didik diberikan soal siswa cenderung malas membaca dan sering bertanya kepada guru tentang isi dalam soal.

Dengan melihat masalah pada pertemuan pertama, peneliti terus mengingatkan kepada peserta didik bagaimana seharusnya yang dilakukan oleh peserta didik sehingga pada pertemuan selanjutnya peserta didik dapat dikondisikan dengan baik, peserta didik mulai aktif dan lebih serius dalam menyelesaikan soal berdasarkan langkah-langkah pada model pembelajaran Discovery Learning.

Berdasarkan penelitian yang telah dilakukan, untuk mendapatkan hasil yang optimal dari penggunaan model pembelajaran Discovery 
Learning menggunakan alat peraga jam baretika yaitu diperlukan interaksi antar peserta didik, tanggung jawab individual dan kerjasama kelompok harus berjalan dengan baik. Selain itu, kemampuan pendidik untuk memotivasi dan memberi penguatan kepada peserta didik diperlukan agar mereka semangat dan antusias dalam belajar pada proses pembelajaran di kelas maupun proses pembelajaran di luar kelas.

\begin{tabular}{|c|c|c|c|c|c|}
\hline \multicolumn{6}{|c|}{ 冓 } \\
\hline Kelompok & $\begin{array}{r}\text { N Rata } \\
\text { rata }\end{array}$ & $\mathrm{Dk}$ & $T_{\text {Hitung }}$ & $T_{\text {Tabel }}$ & Keterangan \\
\hline $\begin{array}{l}\text { Pembelajaran model } \\
\text { Discovery Learning } \\
\text { menggunakan alat } \\
\text { peraga jam baretika }\end{array}$ & $34 \quad 73,26$ & 33 & & & $\begin{array}{l}\text { Pembelajaran } \\
\text { menggunakan alat } \\
\text { peraga jam } \\
\text { baretika }\end{array}$ \\
\hline $\begin{array}{l}\text { Pembelajaran tanpa } \\
\text { model Discovery } \\
\text { Learning menggunakan } \\
\text { alat peraga jam } \\
\text { baretika }\end{array}$ & $33^{62,74}$ & 32 & 3,82 & 1,99 & $\begin{array}{l}\text { berpengaruh } \\
\text { terhadap } \\
\text { pemahaman } \\
\text { konsep siswa }\end{array}$ \\
\hline
\end{tabular}

Gambar 1 Hasil $U j i$ - T terhadap Kemampuan Pemahaman Konsep Grafik uji $-t$ dengan pihak kanan setelah nilai $t$ didapat.

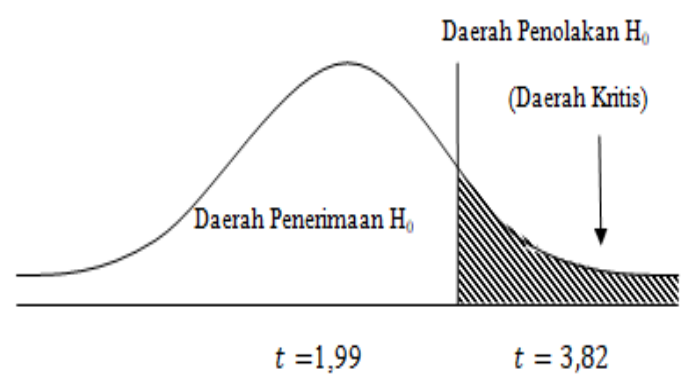

Gambar 2 Grafik Uji- $t$

\section{SIMPULAN}

Model pembelajaran penemuan (discovery learning) merupakan salah satu model pembelajaran yang diutamakan dalam implementasi 
kurikulum 2013 yang mengacu pada keingintahuan siswa dan memotivasi siswa untuk melanjutkan pekerjaannya hingga mereka menemukan jawabannya. Jam Baretika adalah alat peraga yang dibuat berbentuk jam yang mempunyai dua buah jam dengan fungsi berbeda serta mempunyai komponen-kompenen pendukung lainnya. Jam baretika digunakan pada materi barisan dan deret aritmatika yang berfungsi sebagai alat untuk menemukan bilangan-bilangan aritmatika. Jam baretika bertujuan untuk membuat siswa terlibat aktif di dalam menemukan sendiri bilanganbilangan serta konsep barisan dan deret aritmatika. Berdasarkan penelitian yang telah dilakukan, untuk mendapatkan hasil yang optimal dari penggunaan model pembelajaran Discovery Learning menggunakan alat peraga jam baretika yaitu diperlukan interaksi antar peserta didik, tanggung jawab individual dan kerjasama kelompok harus berjalan dengan baik. Selain itu, kemampuan pendidik untuk memotivasi dan memberi penguatan kepada peserta didik diperlukan agar mereka semangat dan antusias dalam belajar pada proses pembelajaran di kelas maupun proses pembelajaran di luar kelas.

\section{DAFTAR PUSTAKA}

A'raf, A. A, Tahmir, S \& Rohman, A. (2015). Keefektifan Penerapan Model Pembelajaran Kooperatif dengan Pendekatan Scietific dalam Pembelajaran Matematika di kelas VIII SMP Negeri 2 Mejene. Jurnal daya matematis. 3(1):63-68

Arikunto, S. (2010). Dasar-Dasar Evaluasi Pendidikan. Jakarta: Bumi Aksara

Fauzia, T. A, Juandi. D \& Purniati, T. (2017). Desain didaktis konsep barisan dan deret aritmetika pada pembelajaran matematika sekolah menengah atas. Jurnal Pendidikan Matematika Indonesia. 1(1): $1-10$

Kemdikbud. (2014). Konsep dan Implementasi Kurikulum 2013. [Online]. (Http://Www.Kemdikbud.go.Id/Kemdikbud/Dokumen/ Paparan/Paparan\%20Wamendik.Pdf, Diakses 2 Maret 2020)

Kodir, A. (2018). Manajemen Pembelajaran Saintifik Kurikulum 2013. Bandung: Pustaka Setia 
Salmi. (2019). Penerapan Model Pembelajaran Discovery Learning dalam Meningkatkan Hasil Belajar Ekonomi Peserta Didik Kelas XII IPS 2 SMA Negeri 13 Palembang. Jurnal Profit. 6(1):1-15

Saifuddin, dkk. (2018). Analysis of the difficulty of students in the points of sequences and series of class X IPS SMA 1 Blora. Jurnal Teladan. 3(2):101 
188 | Purnamasari dan Widyaningrum: Pengaruh Model Pembelajaran Discovery Learning ... 